\title{
The relationship between the surface tension and the saturated vapor pressure of model nanofluids
}

\author{
O. Ya. Khliyeva ${ }^{{ }^{*}}$, D. A. Ivchenko ${ }^{I}$, K. Yu. Khanchych ${ }^{1,2}$, I. V. Motovoy ${ }^{I}$, V. P. Zhelezny ${ }^{I}$ \\ ${ }^{1}$ Odessa National Academy of Food Technologies, 112, Kanatna St., Odesa, 65039, Ukraine \\ ${ }^{2}$ Odessa I.I. Mechnikov National University, 2, Dvorianska St., Odesa, 65082, Ukraine \\ $\bowtie$ e-mail: khliyev@ukr.net
}

\begin{abstract}
Information on surface tension is necessary for modeling boiling processes in nanofluids. It was shown that the problem of predicting the surface tension of complex thermodynamic systems, such as nanofluids, remains outstanding. It should be noted that the surface tension of liquids and the saturated vapor pressure are due to a specific intermolecular interaction in the region of spatial heterogeneity of the substance (surface layer). Moreover, the compositions of the surface layer of nanofluid and its liquid phase are not equal. The presence of nanoparticles in the base fluid affects the composition of the surface layer of liquids. However, there are no methods for determining the composition of the surface layer of nanofluids and this fact complicates establishing the dependence of the surface tension on the state parameters of nanofluids. It should be mentioned that the number of possible methodological errors in measurements of the saturated vapor pressure of nanofluids is significantly lower than for the surface tension measurements. Therefore, in the development of models for predicting the surface tension, scientific and practical interest has establishing the relationship between the surface tension and the saturated vapor pressure of nanofluids. In the presented work, we consider the nanofluids of isopropanol/Al $\mathrm{O}_{2} \mathrm{O}_{3}$ nanoparticles and o-xylenelfullerenes $\mathrm{C}_{60}$. Saturated vapor pressure and surface tension of nanofluids of isopropanol/Al $\mathrm{O}_{3} \mathrm{O}_{3}$ nanoparticles have been studied in the temperature range $293-363 \mathrm{~K}$ and concentrations of $\mathrm{Al}_{2} \mathrm{O}_{3}$ nanoparticles $0-8.71 \mathrm{~g} / \mathrm{kg}$. Measurement of saturated vapor pressure and surface tension of nanofluids of o-xylene/fullerenes $C_{60}$ have been performed in the temperature range $283-348 \mathrm{~K}$ and the concentration of $\mathrm{C}_{60} 0-7.5 \mathrm{~g} / \mathrm{kg}$. It is shown that additives of $\mathrm{Al}_{2} \mathrm{O}_{3}$ nanoparticles and fullerenes $\mathrm{C}_{60}$ lead to a decrease in the surface tension and increase in the saturated vapor pressure. It is shown that there is a universal dependence between the reduced surface tension and saturated vapor pressure for the researched nanofluids.
\end{abstract}

Keywords: Nanofluid, Surface Tension, Saturated Vapor Pressure, Experiment, Predicting Method

doi:

(C) The Author(s) 2019. This article is an open access publication

This work is licensed under the Creative Commons Attribution 4.0 International License (CC BY)

http://creativecommons.org/licenses/by/4.0/

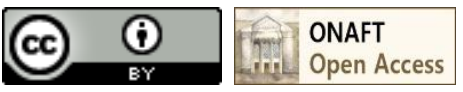

\section{Introduction}

Recently, we can note increasing the interest in studying the prospects of nanofluids as working fluids of vapor compression refrigeration equipment (solution of refrigerant/compressor oil/nanoparticles) and as coolants (heat transfer fluids containing nanoparticles) [1-5]. Therefore, the problem of experimental investigation and predicting of nanofluids thermophysical properties promising for refrigeration is of current importance.

The surface tension of nanofluids is rather difficult measured because two reason. Firstly, the equilibrium in the measuring cell with studied samples is achieved long time [6]. Secondly, the nanoparticles influence interfacial angle. But information on surface tension is necessary for modelling boiling processes with nanofluids.

A number of papers dedicated to development the predicting methods for the surface tension of pure liquids and their mixtures [7-25] have been published from the middle of the last century to the presents. These methods can be divided into two types: empirical correlations and methods based on thermodynamic approaches.
The empirical methods have been widely used and will be used in further. But the experimental investigation of each new multicomponent technical liquid is needed quite large monetary and human labor expenditures.

Methods based on thermodynamic approaches are reviewed in [7-9]. Molecular dynamic simulations were first used in 1976 when Rao et al. [10] presented the possibility of computing the surface tension of a liquid film from statistical thermodynamic relations. Currently, this approach is successfully applied for surface tension predicting for both pure liquid and their mixtures [11]. Nevertheless, models based on molecular dynamics are not suitable for complex thermodynamic systems.

Introduced by Brock and Bird in 1955 the corresponding states principle allows to estimate surface tension from the critical constants [12]. Curl and Pitzer improved this model, which is restricted to short and weakly polar molecules by introducing an acentric shape parameter [13]. For example, in recently published papers $[14,15]$ new simple correlations based on the principles are corresponding states proposed to estimate the temperature-dependent liquids surface tension. The new correlations were obtained by 
fitting surface tension data of number different liquids (refrigerants, hydrocarbons and some other inorganic liquids). The new correlations have several fitting coefficients and require such input data: critical point temperature, triple point temperature and surface tension or temperature and surface tension values at the boiling point.

Group contribution-based methods are popular approaches to predict physicochemical properties. For purpose of surface tension prediction, a model was introduced by Egemen et al. in 2000 [16]. Moreover, an extended model was proposed by Conte et al [17]. Li et al. [18] presented a new method based on a combination of corresponding-states and group contribution models. In addition, Zhelezny et al. proposed a new scaling principlequantitative structure-property relationship method for predicting the physicochemical (including surface tension) properties [19].

As can we see from short review, the major number of studies on predicting the surface tension considered pure liquids. There is some progress in predicting the surface tension of various mixtures using the thermodynamic approach $[11,20,21]$. There are some studies dedicated predicting the surface tension of mixtures refrigerants and solutions of refrigerant in compressor oil [5, 7, 22, 23], that we are interested in. But studies dedicated predicting the surface tension of nanofluids are absence at present. Based on mentioned, we can be stated that the problem of predicting the surface tension of complex thermodynamic systems, such as nanofluids, remains outstanding.

It should be noted that the surface tension of liquids and the saturated vapor pressure are due to a specific intermolecular interaction in the region of spatial heterogeneity of the substance (surface layer). Moreover, the compositions of the surface layer of solutions and nanofluids and their bulk liquid phase are not equal [23]. The presence of nanoparticles in the base fluid affects the composition and structure of the surface layer of liquids. However, there are no methods for determining the composition of the surface layer of nanofluids and this fact complicates establishing the dependence of the surface tension on the state parameters of nanofluids.

It should be mentioned that the number of possible methodological errors in measurements of the saturated vapor pressure of nanofluids is significantly lower than for the surface tension measurements. Therefore, scientific and practical interest has establishing the relation between the surface tension and the saturated vapor pressure of nanofluids when developing the predicting models on surface tension.

\section{Objects of study}

The objects of study were been two fluids: nanofluids isopropanol/ $/ \mathrm{Al}_{2} \mathrm{O}_{3}$ nanoparticles and solution of fullerenes $\mathrm{C}_{60}$ in o-Xylene.

Sigma-Aldrich isopropanol/ $\mathrm{Al}_{2} \mathrm{O}_{3}$ nanofluid (Product № 702129 ) with a nanoparticle content of $0.20 \pm 0.01 \mathrm{~kg} \cdot \mathrm{kg}^{-1}$ was used in this study. This nanofluid was chosen because isopropanol forms stable over time colloidal solutions with $\mathrm{Al}_{2} \mathrm{O}_{3}$ nanoparticles over a wide range of concentrations and temperatures [26]. According to the manufacturer, the size of the $\mathrm{Al}_{2} \mathrm{O}_{3}$ nanoparticles (CAS 1344-28-1) was not greater than $50 \mathrm{~nm}$ (dynamic light scattering) with a purity of $99.9 \%$ (Trace Metals Analysis). Samples were prepared by diluting the nanofluid № 702129 with isopropyl alcohol (CAS 67-63-0, 99.7\% purity). Diluted nanofluid was homogenized by simple, short term mechanical shaking.

o-Xylene was chosen as base fluid due to it is good solvent for fullerene $\mathrm{C}_{60}$ over a wide range of concentrations and temperatures [27]. According to the manufacturer (Suzhou Dade Carbon Nanotechnology Co., Ltd), the purity of $\mathrm{C}_{60}$ (CAS 99685-96-8) was not less than 99.5\%. Samples were prepared by mixing the fullerenes $\mathrm{C}_{60}$ with o-xylene (CAS 95-47-6, 99.7\% purity). Solution was homogenized by sonication for 2 hours using the ultrasonic bath.

Colloidal stability of nanofluid isopropanol/ $/ \mathrm{Al}_{2} \mathrm{O}_{3}$ nanofluids was studied in our previous paper [26] and excellent stability for wide nanoparticles mass fraction range was shown. Mass fraction of $\mathrm{C}_{60}$ in o-Xylene was chosen in accordance with [27] to provide full solubility of fullerenes without clasterisation.

\section{An experimental investigation of the surface tension and saturated vapor pressure}

Determination of the saturated vapor pressure $P_{S}$ for the samples has been performed by a static experimental method. An experimental setup has been designed in order to measure the saturation vapor pressure of the nanofluids. A schematic outline of the experimental setup is shown in Fig. 1.

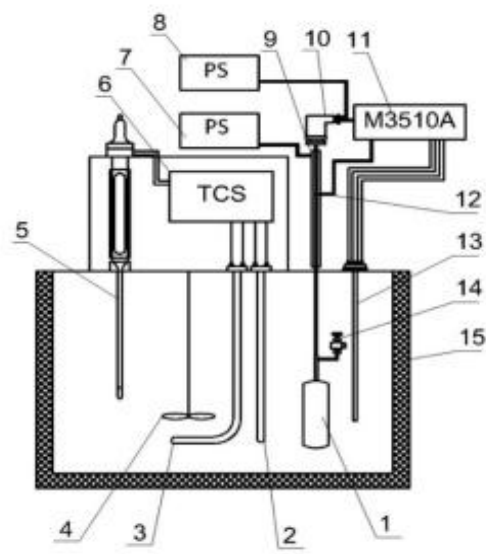

Figure 1 - Schematic of experimental setup for investigation of the saturation vapor pressure of the nanofluids: 1 Experimental cell; 2 - Background heater; 3 - Booster heater; 4 - Mixer; 5 - Contact thermometer, 6 - Temperature control system; 7 - DC power supply B5-44; 8 - DC power supply B5-49; 9 - Heater for ballast capillary; 10 - Pressure transducer WIKA S-10; 11 - Multimeter M3510A; 12 Thermocouple (DT838); 13 - Platinum resistance thermometer TR10A; 14 - Valve; 15 - Thermostat.

For investigation the effect of $\mathrm{Al}_{2} \mathrm{O}_{3}$ nanoparticles and $\mathrm{C}_{60}$ additives on the surface tension $\sigma$ the modified differential method of capillary rise has been applied. The essence of this method is the measurements of the difference for height of rising of the liquid's meniscus in a few capillary pair and following calculation of the weighted average value of capillary constant $a^{2}$. This makes it possible to significantly increase the accuracy of the experimental data. A schematic outline of the experimental setup is given in Fig. 2. 


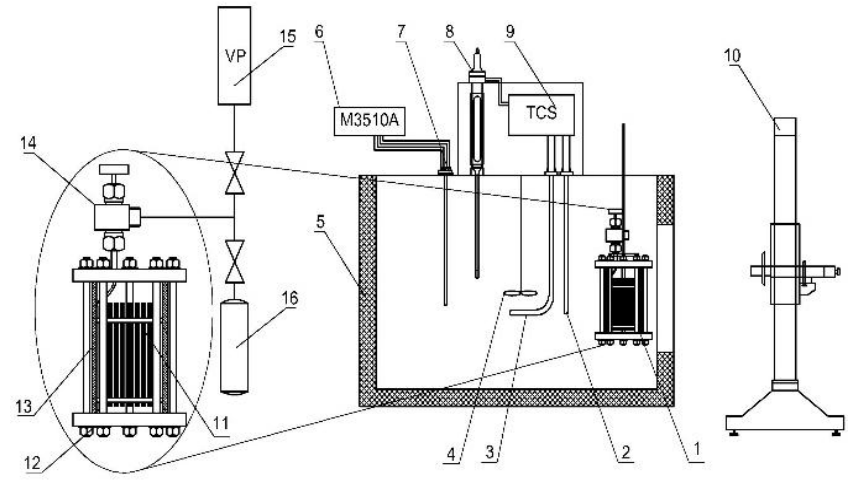

Figure 2 - Schematic of experimental setup for investigation of the surface tension of the nanofluids: 1 - Experimental cell; 2 - Background heater; 3 - Regulating heater; 4 - Mixer; 5 - Thermostat; 6 - Multimeter M3510A; 7 - Platinum resistance thermometer TR10A; 8 - Contact thermometer, 9 - Temperature control system; 10 - Cathetometer; 11 - Capillaries; 12 - Flange; 13 - Glass

Saturated vapor pressure and surface tension of samples have been studied in the temperature range 293-363 $\mathrm{K}$ and mass fraction range of $\mathrm{Al}_{2} \mathrm{O}_{3} \quad 0-8.71 \mathrm{~g} \cdot \mathrm{kg}^{-1}$ nanoparticles. Measurement of saturated vapor pressure and surface tension of solutions of o-xylene/fullerenes $\mathrm{C}_{60}$ have been performed in the temperature range 283-348 $\mathrm{K}$ and the mass fraction range of $\mathrm{C}_{60} 0-7.5 \mathrm{~g} \cdot \mathrm{kg}^{-1}$.

The surface tension, capillary constant and densities of the liquid and vapor phases of studied liquids are related as

$$
\sigma=0.5 \cdot g \cdot a^{2} \cdot\left(\rho^{\prime}-\rho^{\prime \prime}\right),
$$

where $\rho^{\prime}$ and $\rho^{\prime \prime}$ are the density of liquid and vapor phases, respectively; $g$ is an acceleration of gravity; $a^{2}$ is the capillary constant.

It is shown that additives of $\mathrm{Al}_{2} \mathrm{O}_{3}$ nanoparticles and fullerenes $\mathrm{C}_{60}$ lead to a decrease in the surface tension and increase in the saturated vapor pressure.

The experimental data on saturated vapor pressure and surface tension for nanofluids isopropanol/ $\mathrm{Al}_{2} \mathrm{O}_{3}$ nanoparticles and solution o-Xylene/fullerene $\mathrm{C}_{60}$ were fitted as $P_{S}=f\left(w_{A l 2 O 3(C 60)}, T\right)$ and $\sigma=f\left(w_{A l 2 O 3(C 60)}, T\right)$. The experimental and fitted data on surface tension and saturated vapor pressure are presented in Figs. 3-6.

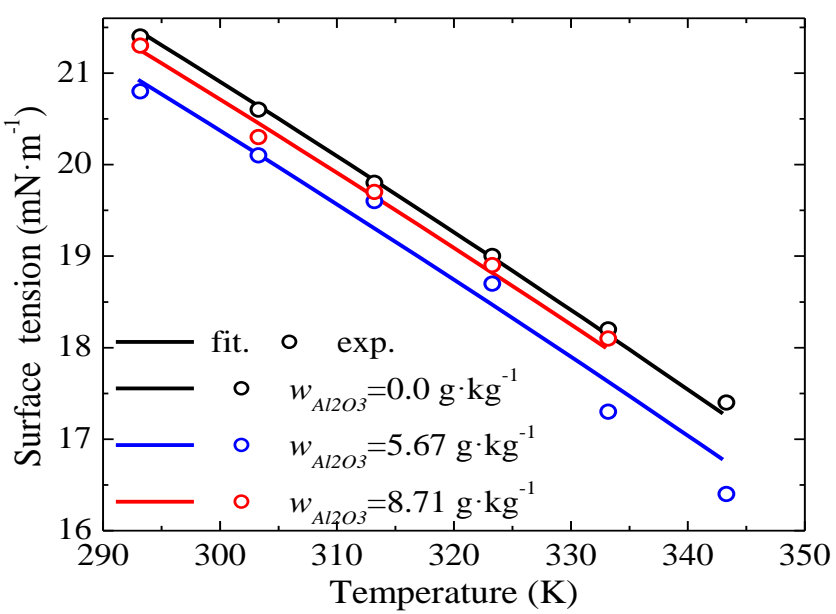

Figure 3 - Temperature dependencies on the surface tension for the nanofluids isopropanol/ $/ \mathrm{Al}_{2} \mathrm{O}_{3}$

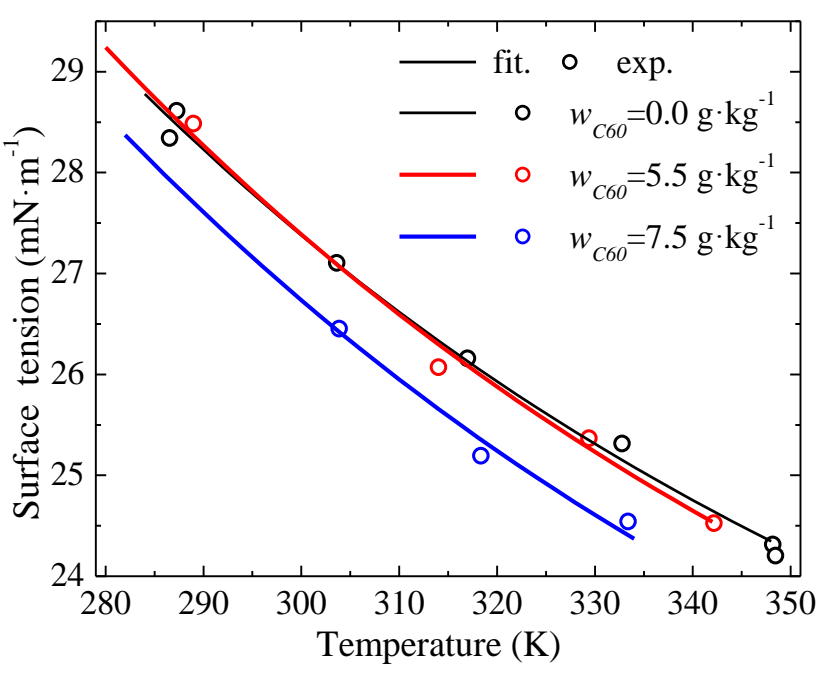

Figure 4 - Temperature dependencies on the surface tension for the o-xylene/fullerene

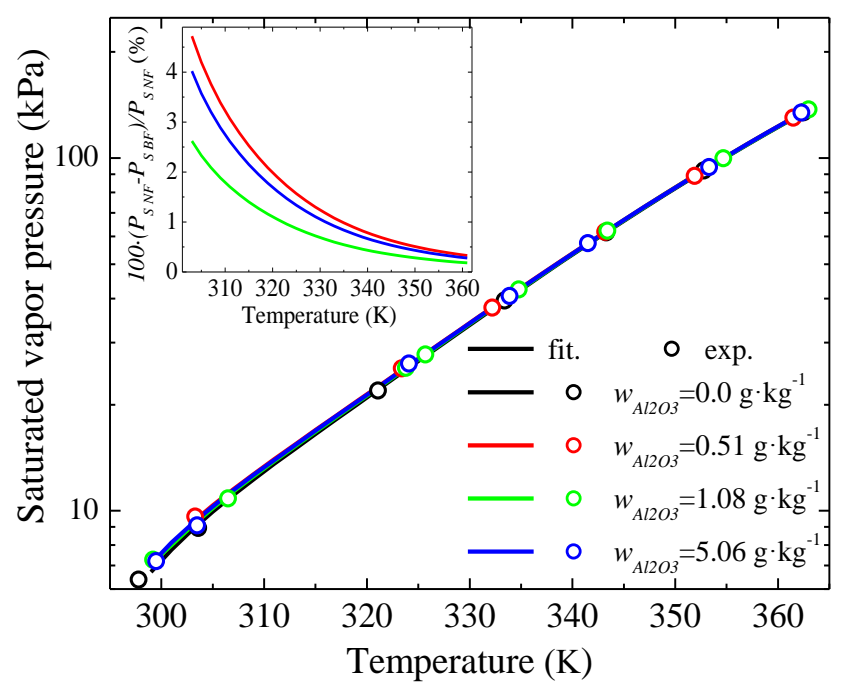

Figure 5-Temperature dependencies on the saturated vapor pressure for the nanofluids isopropanol/ $\mathrm{Al}_{2} \mathrm{O}_{3}$

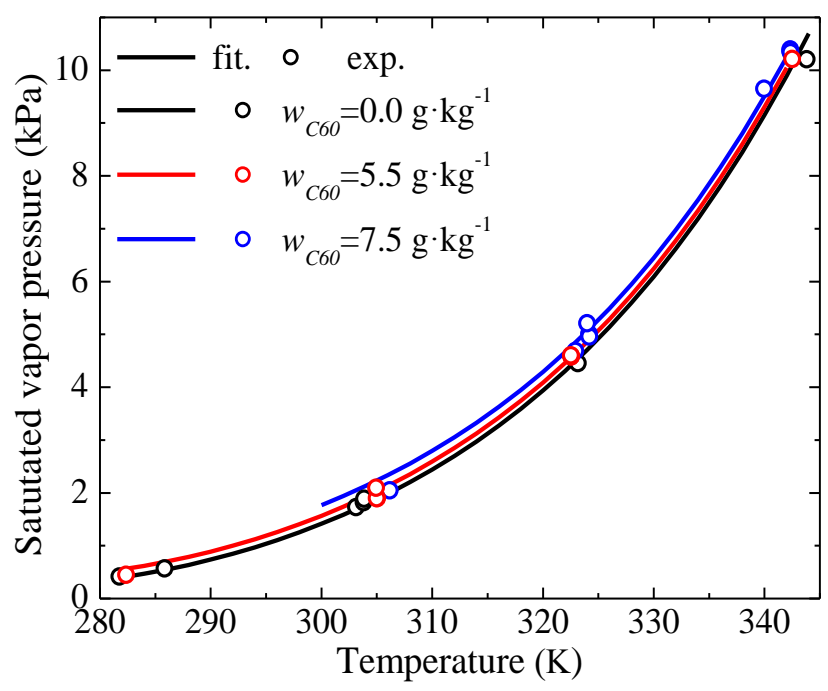

Figure 6 - Temperature dependencies on the saturated vapor pressure for the o-xylene/fullerene $\mathrm{C}_{60}$ solutions 
The dependencies on the saturated vapor pressure from surface tension at different mass fraction of nanoparticles $\mathrm{Al}_{2} \mathrm{O}_{3}$ or fullerenes $\mathrm{C}_{60}$ for the nanofluids isopropanol $/ \mathrm{Al}_{2} \mathrm{O}_{3}$ and for solutions o-xylene/ $\mathrm{C}_{60}$ demonstrated Figs. 7-8.

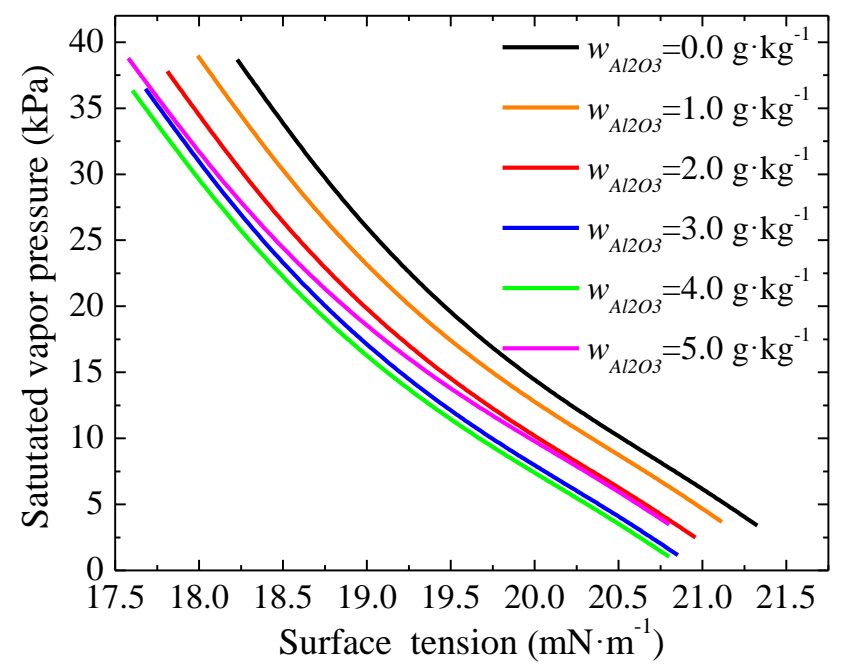

Figure 7 - The dependencies on the saturated vapor pressure from surface tension at different mass fraction of nanoparticles $w_{A l 2 O 3}$ for the nanofluids isopropanol $/ \mathrm{Al}_{2} \mathrm{O}_{3}$

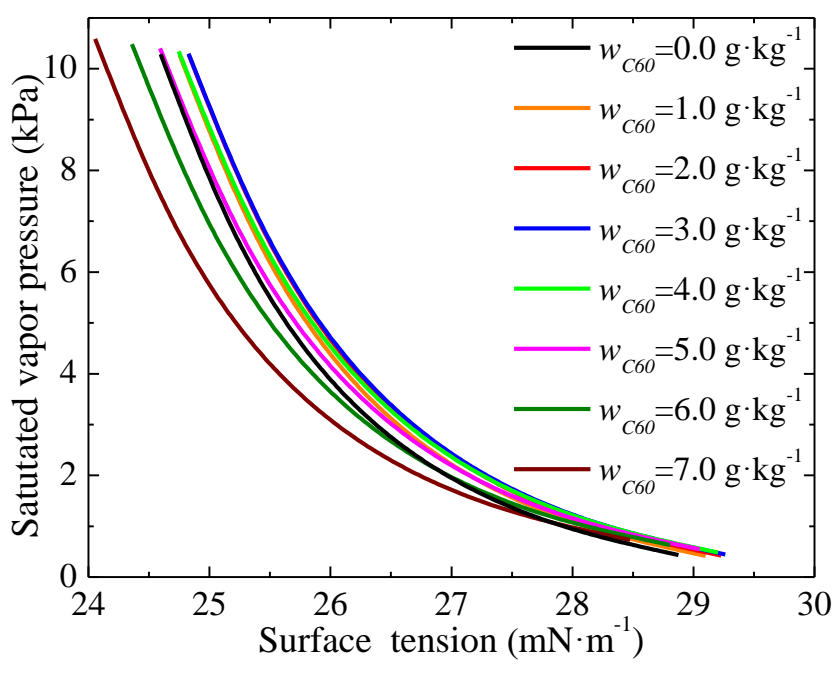

Figure 8 - The dependencies on the saturated vapor pressure from surface tension at different mass fraction of fullerenes $w_{C 60}$ for the o-xylene/fullerene $\mathrm{C}_{60}$ solutions

Analysis of obtained experimental data shows there is a relationship between the saturated vapor pressure and surface tension for the objects of study at all ranges of nanoparticles mass fractions.

Previously similar conclusion has been obtained for halogen hydrocarbons and its solution with mineral compressor oils [23]. This conclusion can use to develop the methods for surface tension prediction with using the more available and precision information about saturated vapor pressure of liquids, solutions or nanofluids.

The graphics confirmation of presence the relationship between the saturated vapor pressure, surface tension and nanoparticles mass fraction are shown on Figs. 9 and 10.

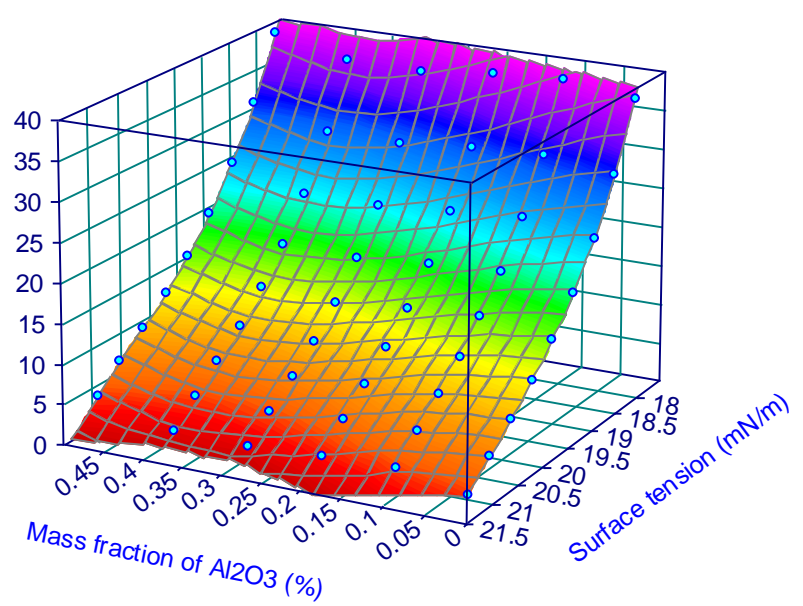

Figure 9 - Relationship between the saturated vapor pressure, surface tension and nanoparticles $\mathrm{Al}_{2} \mathrm{O}_{3}$ mass fraction for nanofluid isopropanol/ $\mathrm{Al}_{2} \mathrm{O}_{3}$ in temperature range 293 $333 \mathrm{~K}$

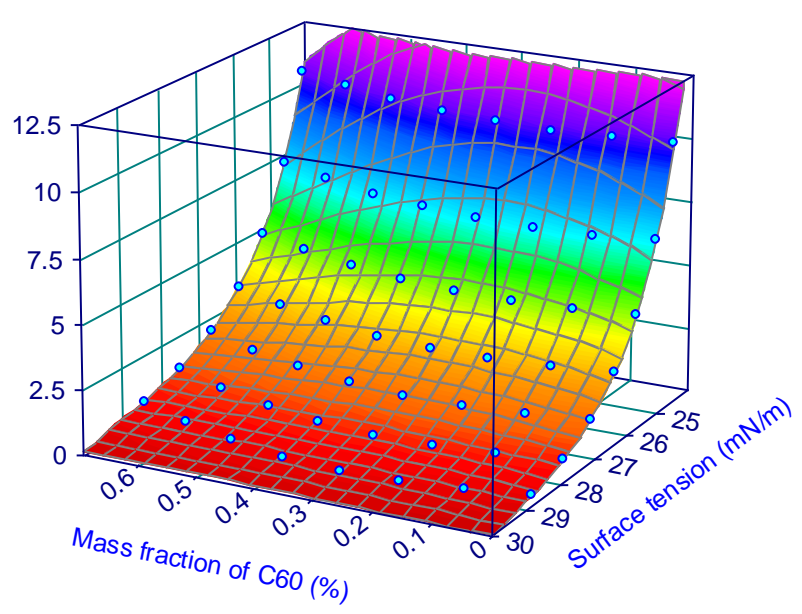

Figure 10 - Relationship between the saturated vapor pressure, surface tension and fullerenes $\mathrm{C}_{60}$ mass fraction for solution o-Xylene/ $\mathrm{C}_{60}$ in temperature range $283-343 \mathrm{~K}$

\section{Relationship between surface tension and satu- rated vapor pressure for nanofluids}

The functional relationship between the surface tension and saturated vapor pressure of the liquids was examined using following reduced parameters:

$$
\begin{gathered}
\varphi(t)=\frac{\sigma(t)}{\sigma_{n b}}, \\
\pi(t)=\ln \left(\frac{P_{C}}{P_{S}(t)}\right),
\end{gathered}
$$

where $\varphi, \pi$ are reduced surface tension and saturated vapor pressure; $\sigma_{n b}$ is the surface tension of a saturated liquid at the normal boiling point; $P_{C}$ is the critical pressure; $t=1-T / T_{C}$ is the reduced temperature; $T_{C}$ is the critical temperature.

In our previous paper [23] it was demonstrated the existence of the functional relationship between the surface tension and saturated vapor pressure for the pure liquids. It 
makes it possible to predict the surface tension of pure liquids in a wide temperature range, using available information on the saturated vapor pressure. Analysis of the relationship between functions $\varphi$ and $\pi$ for different hydrocarbons showed similar behavior (see Fig. 11, [23]).

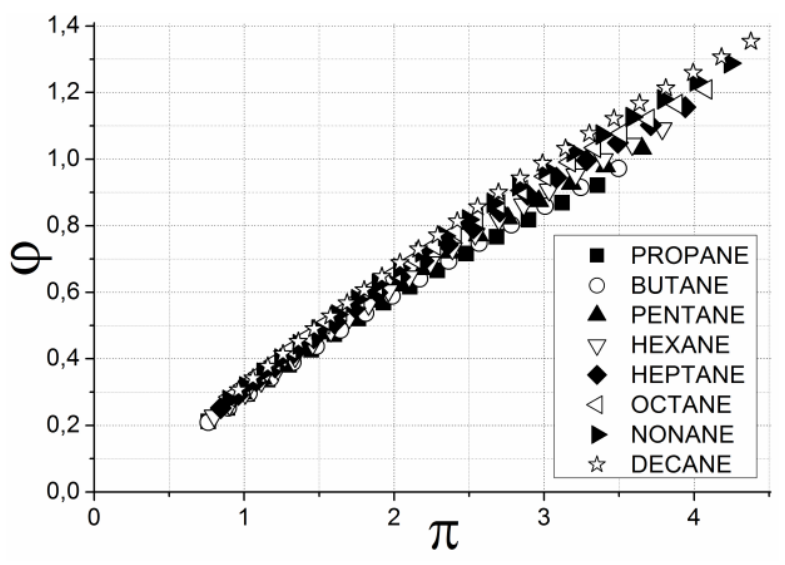

Figure 11 - Relationship between $\varphi$ and $\pi$ for some hydrocarbons [23]

The main difficulty to establish the relationship $\varphi(t)=f(\pi(t))$ for nanofluids is lack of information about its pseudocritical pressure.

But as was shown in [5] the additives of nanoparticles do not lead to significant variation in pseudocritical pressure. Therefore as an assumption we use the constant value of pseudocritical pressure equal the value for pure base fluid. At the first stage of the study was established the relationship $\varphi(t)=f(\pi(t))$ for nanofluids isopropanol/ $\mathrm{Al}_{2} \mathrm{O}_{3}$ in temperature range $298-343 \mathrm{~K}$ (Fig. 12) and for solutions $\mathrm{o}-\mathrm{Xylene} / \mathrm{C}_{60}$ in temperature range $283-348 \mathrm{~K}$ (Fig. 13).

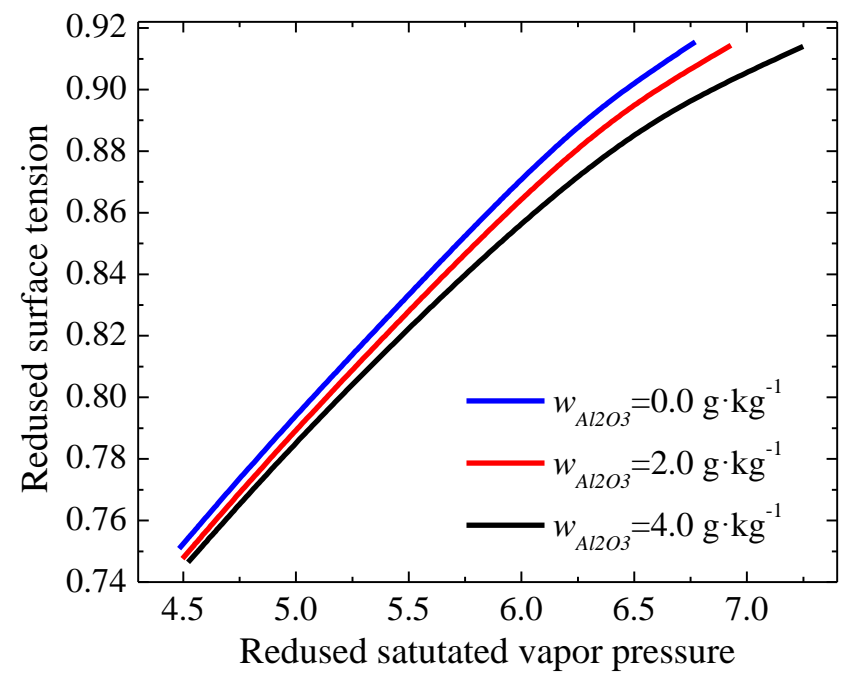

Figure 12 - Relationship between $\varphi$ and $\pi$ for nanofluids isopropanol $/ \mathrm{Al}_{2} \mathrm{O}_{3}$ in temperature range $298-343 \mathrm{~K}$

Analysis of the relationship between functions $\varphi$ and $\pi$ for studied nanofluids at different mass fraction of nanoparticles show presence almost linear dependences (see Fig. 13). This makes possible to predict the surface tension of nanofluids in a wide temperature range using available information on the saturated vapor pressure.

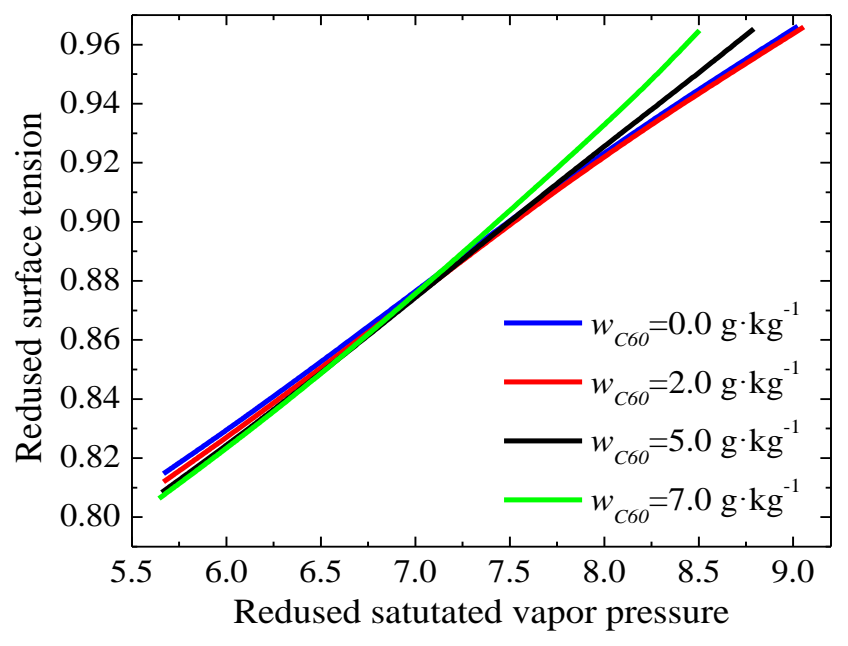

Figure 13 - Relationship between $\varphi$ and $\pi$ for solutions oXylene/ $\mathrm{C}_{60}$ in temperature range $283-348 \mathrm{~K}$

In our further research we are going to evaluate pseudocritical temperature and pressure for nanofluid isopropanol/ $/ \mathrm{Al}_{2} \mathrm{O}_{3}$ and solution o-xylene/ $\mathrm{C}_{60}$ with using the methodology [5] and estimate functional relationship between surface tension and saturated vapor pressure for the studied nanofluids.

\section{Conclusion}

Based on obtained experimental data the several conclusions can be made.

The nanoparticles $\mathrm{Al}_{2} \mathrm{O}_{3}$ and fullerenes $\mathrm{C}_{60}$ additives lead to decrease the surface tension and increase the saturated vapor pressure at different mass fraction of additives in base fluids. We assume that the reason for these effects is the difference between the effective mass fraction of nanoparticles in the surface layer of nanofluid and the mass fraction of nanoparticles in the bulk of liquid phase. This effect, as well as the presence of adsorption molecules of base fluid on the nanoparticles surface in the nanofluid, leads to a change in the structure of the surface layer of nanofluids. In the surface layer the forces of mutual attraction between the molecules of the base fluid decrease, which contributes to a decrease in surface tension and an increase in saturated vapor pressure.

It was shown that relationship between reduced surface tension and reduced saturated vapor pressure for studied nanofluids at different mass fraction of nanoparticles has almost linear dependences. This makes possible to predict the surface tension of nanofluids in a wide temperature range using available information on the saturated vapor pressure.

Goal of authors's further studies is establishment of a functional relationship between reduced surface tension and reduced saturated vapor pressure for different nanofluids.

\section{References}

1. Bhattad, A., Sarkar, J., Ghosh, P., 2018. Improving the performance of refrigeration systems by using nanofluids: 
A comprehensive review. Renew. Sust. Energ. Rev. 82 , 3656-3669. https://doi.org/10.1016/j.rser.2017.10.097

2. Patil, M., Kim, S., Seo, J. H., Lee, M. Y., 2016. Review of the thermo-physical properties and performance characteristics of a refrigeration system using refrigerant-based nanofluids, Energies. 9 (1), 22. https://doi.org/10.3390/ en9010022

3. Azmi, W. H., Sharif, M. Z., Yusof, T. M., Mamat, R., Redhwan, A. A. M., 2017. Potential of nanorefrigerant and nanolubricant on energy saving in refrigeration systemA review. Renew. Sust. Energ. Rev. 69, 415-428. https://doi.org/10.1016/j.rser.2016.11.207

4. Celen, A. Çebi, A., Aktas, M., Mahian, O., Dalkilic, A. S., Wongwises, S., 2014. A review of nanorefrigerants: flow characteristics and applications. Int. J. Refrig. 44, 125140. https://doi.org/10.1016/j.ijrefrig.2014.05.009

5. Zhelezny, V., Lukianov, N., Khliyeva, O., Nikulina, A., Melnyk, A., 2017. A complex investigation of the nanofluids R600a-mineral oil-A12O3 and R600a-mineral oil-TiO2. Thermophysical properties. Int. J. Refrig. 74, 488-504. https://doi.org/10.1016/j.ijrefrig.2016.11.008

6. Zhelezny, P. V., Zhelezny, V. P., Procenko, D. A., Ancherbak, S. N., 2007. An experimental investigation and modelling of the thermodynamic properties of isobutanecompressor oil solutions: Some aspects of experimental methodology. Int. J. Refrig. 30(3), 433-445. https://doi.org/10.1016/j.ijrefrig.2006.09.007

7. Shestova, T. D., Lozovsky, T. L., Zhelezny, V. P., 2014. Modifying gradient theory to predict the surface properties of halogenated hydrocarbons. Russ. J. Phys. Chem. A. 88(5), 851-857. https://doi.org/10.1134/S0036 024414050288

8. Goussard, V., Duprat, F., Gerbaud, V., Ploix, J. L., Dreyfus, G., Nardello-Rataj, V., Aubry, J. M., 2017. Predicting the Surface Tension of Liquids: Comparison of Four Modeling Approaches and Application to Cosmetic Oils. J. Chem. Inf. Model. 57(12), 2986-2995. https://doi.org/10.1021/acs.jcim.7b00512

9. Baidakov, V. G., Khotienkova, M. N., 2016. Surface tension of methane-nitrogen solutions: 2. Description in the framework of the van der Waals gradient theory. Fluid Ph. Equilibria. 425, 402-410. https://doi.org/10.1016/j.fluid. 2016.06.038

10. Rao, M., Levesque, D., 1976. Surface Structure of a Liquid Film. J. Chem. Phys. 65, 3233-3236. https://doi.org/ 10.1063/1.433495

11. Protsenko, S. P., Baidakov, V. G., 2016. Binary Lennard-Jones mixtures with highly asymmetric interactions of the components. 1. Effect of the energy parameters on phase equilibria and properties of liquid-gas interfaces. Fluid Ph. Equilibria. 429, 242-253. https://doi.org/ 10.1016/j.fluid.2016.09.009

12. Brock, J. R., Bird, R. B., 1955. Surface Tension and the Principle of Corresponding States. AIChE J. 1, 174-177. https://doi.org/10.1002/aic.690010208

13. Curl, R. F., Pitzer, K., 1958. Volumetric and Thermodynamic Properties of Fluids-enthalpy, Free Energy, and Entropy. Ind. Eng. Chem. 50, 265-274. https://doi.org/ 10.1021/ie50578a047

14. Yi, H., Tian, J., 2015. New generalized corresponding states correlation for surface tension of normal saturated liquids. Int. J. Mod. Phys. B. 29(22), 1550156. https://doi.org/10.1142/S0217979215501568
15. Cachadiña, I., Mulero, A., Tian, J., 2017. Surface tension of refrigerants: A new correlation using the boiling point as reference. Fluid Ph. Equilibria. 442, 68-80. https://doi.org/10.1016/j.fluid.2017.03.017

16. Egemen, E., Nirmalakhandan, N., Trevizo, C., 2000. Predicting Surface Tension of Liquid Organic Solvents. Environ. Sci. Technol. 34, 2596-2600. https://doi.org/ 10.1021/es991284u

17. Conte, E., Martinho, A., Matos, H. A., Gani, R., 2008. Combined GroupContribution and Atom Connectivity Index-Based Methods for Estimation of Surface Tension and Viscosity. Ind. Eng. Chem. Res. 47, 7940-7954. https://doi.org/10.1021/ie071572w

18. Li, P., Ma, P.-S., Dai, J.-G., Cao, W., 1996. Estimations of Surface Tensions at Different Temperatures by a Corresponding-States GroupContribution Method. Fluid Ph. Equilib. 118, 13-26. https://doi.org/10.1016/03783812(95)02836-6

19. Zhelezny, V., Sechenyh, V., Nikulina, A., 2014. A New Scaling Principles-Quantitative Structure Property Relationship Model (SP-QSPR) for Predicting the Physicochemical Properties of Substances at the Saturation Line. J. Chem. Eng. Data. 59(2), 485-493. https://doi.org/10.1021/je400933x

20. Garrido, J. M., Mejía, A., Piñeiro, M. M., Blas, F. J., Müller, E. A., 2016. Interfacial tensions of industrial fluids from a molecular- based square gradient theory. AIChE Journal, 62(5), 1781-1794. https://doi.org/10.1002/ aic. 15190

21. Hajra, B., Kumar, M., Pathak, A. K., Guria, C., 2016. Surface tension and rheological behavior of sal oil methyl ester biodiesel and its blend with petrodiesel fuel. Fuel. 166, 130-142. https://doi.org/10.1016/j.fuel.2015. 10.109

22. Nabipour, M., 2018. Prediction of surface tension of binary refrigerant mixtures using artificial neural networks. Fluid Ph. Equilibria. 456, 151-160. https://doi.org/ 10.1016/j.fluid.2017.10.020

23. Zhelezny V., Sechenyh V., Ivchenko D., Semenyuk Yu., 2014. Prediction of the surface tension for refrigerants and refrigerant-oil solutions (ROS). Int. J. Refrig. 40, 241 245. https://doi.org/10.1016/j.ijrefrig.2013.12.003

24. Zhang, C., Yi, H., Tian, J., 2016. Lielmezs-Herrick correlation for the temperature-dependent surface tension of hydrocarbons. Int. J. Mod. Phys. B. 30(23), 165-154. https://doi.org/10.1142/S021797921650154X

25. Lashkarbolooki, M., Bayat, M., 2018. Prediction of surface tension of liquid normal alkanes, 1-alkenes and cycloalkane using neural network. Chem. Eng. Res. Des. 137, 154-163. https://doi.org/10.1016/j.cherd.2018.07.021

26. Zhelezny V., Geller V., Semenyuk Y., Nikulin A., Lukianov N., Lozovsky T., Shymchuk M., 2018. Effect of Al2O3 Nanoparticles9 Additives on the Density, Saturated Vapor Pressure, Surface Tension and Viscosity of Isopropyl Alcohol. Int. J. Thermophys. 39 (3), 38. https://doi.org/ 10.1007/s10765-018-2361-8

27. Semenov, K. N., Charykov, N. A., Keskinov, V. A., Piartman, A. K., Blokhin, A. A., Kopyrin, A. A., 2009. Solubility of light fullerenes in organic solvents. J. Chem. Eng. Data. 55(1), 13-36. https://doi.org/10.1021/je900296s

Received 22 December 2018 Approved 05 February 2019 Available in Internet 03 March 2019 


\title{
Взаємозв'язок між поверхневим натягом та тиском насичених парів для модельних нанофлюїдів
}

\author{
О. Я. Хлісва ${ }^{1 凶}$, Д. О. Івченко ${ }^{I}$, К. Ю. Ханчич ${ }^{1,2}$, I. В. Мотовой ${ }^{1}$ В. П. Желєзний \\ ${ }^{1}$ Одеська національна академія харчових технологій, вул. Канатна, 112, Одеса, 65039, Україна \\ ${ }^{2}$ Одеський національний університет ім. I.I. Мечникова, вул. Дворянська, 2, Одеса, 65082, Україна \\ $\bowtie$ e-mail: khliyev@ukr.net
}

Для моделювання прочесів кипіння нанофлюїдів необхідна інформаџія про їх поверхневий натяг. В роботі показано, щцо питання прогнозування поверхневого натягу складних термодинамічних систем, таких як нанофлюіди, остається невиріменим. Слід зазначити, щя поверхневий натяг рідин і тиск насичених парів обумовлені спеицфічною міжмолекулярною взаємодією в області просторової неоднорідності речовини (поверхневого шару в області границі розділу рідкої та газоподібної фаз). Склад поверхневого шару нанофлюїду і рідкої фази в об'ємі нанофлюїду не рівні. Наявність наночастинок в базовій рідині впливає на склад поверхневого шару рідин. Однак відсутні методи визначення складу поверхневого шару нанофлюїду, що ускладнює встановлення залежності поверхневого натягу від параметрів стану нанофлюїдів. Слід зазначити, щуо кількість можливих методологічних похибок вимірювання тиску насичених парів нанофлюїдів значно нижче, ніж при вимірюванні поверхневого натягу. Тому при розробці моделей прогнозування поверхневого натягу науковий $і$ практичний інтерес має встановлення взаємозв'язку між поверхневим натягом і тиском насичених парів нанофлюїдів. В представленій роботі об'єктами дослідження були нанофлюїди ізопропанол/наночастики Al2O3 та о-ксилол/фулерени C60. Тиск насичених парів та поверхневий натяг для нанофлюїду ізопропанол/наночастики Al2O3 були експериментально визначені в інтервалі температур $293-363 \mathrm{~K}$ та при конщентрації наночастинок Аl2О3 0-8,71 г/кг, а для системи о-ксилол / фулерени С60 - в інтервалі температур 283 - 348 К та при концентрації фулеренів C60 0-7,5 г/кг. Показано, щуо добавки наночастинок Al2O3 та фулеренів С60 ведуть до збільшення тиску насичених парів та до зниження поверхневого натягу базових рідин. В роботі наведено аналіз взаємовідношення між величинами зведеного поверхневого натягу та зведеного тиску насичених парів. Показано, щчо існує універсальна залежність між зведеними значеннями поверхневого натягу і тиску насичених парів для досліджуваних нанофлюїдів.

Ключові слова: Нанофлюїд, Поверхневий натяг, Тиск насичених парів, Експеримент, Метод прогнозування 